\title{
シンポジウム
}

\section{「スーパーアドヴァンス症例への対応, 進行再発癌に対する集学的治療}

一根治治療の可否判定と治療指針について一」

\section{口腔癌局所・頸部再発例に対する治療の現状と今後の展望}

\author{
梅 田 正 博 ${ }^{1)}$ 柳本 惣 市 ${ }^{1)}$ 山田慎 - 1) \\ 南川 勉 ${ }^{2)}$ 渋 谷恭 之 ${ }^{2)}$ 古 森 孝 英 ${ }^{2)}$
}

\begin{abstract}
要旨: 手術を行った口胿扁平上皮癌 324 例のうち局所または頸部に再発を生じた症例について後ろ向きに検討した。 局所再発は 26 例 $(8.0 \%)$ に生じ, $\mathrm{T}$ 分類別では T1-2 $: 4.3 \%$, T3-4 $: 17 \%$ の再発率であった。局所再発例のうち救済 可能であったのは 12 例のみで, 特に進展癌の局所再発例の予後は著しく不良であった。再発部位としては咀縞筋隙再 発が多かった。

郭清側の頸部再発は頸部郭清を施行した 199 例中 12 例（6.0\%）にみられた。このうち最終的に頸部が制御できたの は 3 例のみで, うち 2 例はその後遠隔転移を生じており, 靧部郭清後に同側頸部再発を生じた症例の予後は著しく不 良であった。頸部再発部位としては舌骨傍領域や郭清範囲の境界領域が多かった。

局所・頸部再発を防ぐための方策として, 内側咀嚼筋隙郭清, 舌リンパ節へのアプローチ, 高用量シスプラチン併 用の術後化学放射線療法などについて考察した。
\end{abstract}

キーワード : 口腔癌, 局所再発, 頸部再発, 予後

\section{緒言}

画像診断の精度の向上や再建手術の進歩とともに，近 年, 口腔癌手術後の局所・頸部制御率は著しく向上した。 しかし頻度は少ないものの局所・頸部再発のため予後不良 となる症例も少なからずある。いったん再発を生じると救 済手術は拡大切除をしても必ずしも容易ではなく, 手術療 法の限界があるのも事実である。しかし再発時に手術以外 の治療法を選択すると救命できる可能性はさらに低くなる ことから，手術を中心とした集学的治療が行われているの が現状である。

今回，筆者がこれまで経験した口腔癌手術後局所・頸部 再発例を後乃向きに検討し, 再発様式の特徵や二次治療後 の治療経過を明らかにするとともに, 少数ではあるが手術 以外の方法で制御できた症例について供覧する。さらに再 発を予防するための手術術式の工夫や術後治療のあり方に ついても考察したので報告する。

1) 長崎大学大学院医歯薬学総合研究科展開医療科学講座 口腔腫瘍治療学分野 (主任 : 梅田正博教授)

2) 神戸大学大学院医学研究科外科系講座口腔外科学分野 (主任：古森孝英教授）

〔受付：2014 年 6 月 5 日，受理：2014 年 11 月 10 日〕

\section{材料および方法}

2000 年より 2012 年までに筆者が神戸大学医学部口腔外 科および長崎大学歯学部口腔外科において手術を施行した 口腔扁平上皮癌 324 例について後ろ向きに調査を行い, 局 所・頸部再発例の特徴や再発時の治療法, 治療経過などに ついて検討した。

\section{結 果}

\section{1. 局所再発例}

324 例中局所再発は 26 例（8.0\%）に生じた。 $\mathrm{T}$ 分類別 の局所再発率は T1-2 で 230 例中 10 例 $(4.3 \%)$, T3-4 で 94 例中 16 例（17\%）となっており，進展例ほど局所再発 が多いという結果であった。

局所再発例の予後は，T1-2 の再発例 10 例のうち 7 例 （70\%）は salvage できたのに対し，T3-4 の再発例 16 例 では salvage 可能であったのは 5 例 $(31.3 \%)$ のみと, 特 に進展癌でいったん局所再発を生じた場合，予後は著しく 不良であった。以下に局所再発のみられた代表例を供覧す る。

症例 1 （図 1）は 74 歳女性, 左側下顎歯肉扁平上皮癌 （T4aN2bM0）で, 左側全頸部郭清変法, 下顎骨半側切除, 


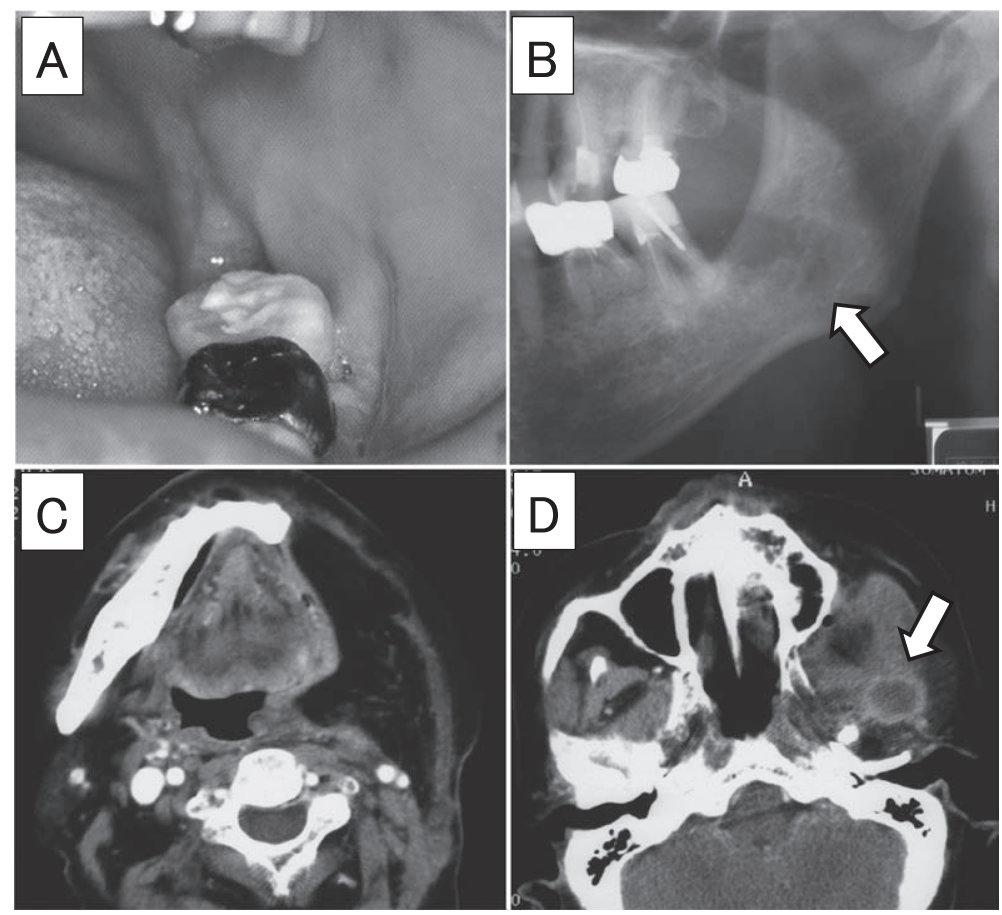

図 1 症例 $1 \mathrm{~A}$ ：初診時口腔内。 $\mathrm{B}$ ：下顎骨深部への浸潤を認めた。C：手術 直後の CT。D : 6 か月後咀嚼筋隙より再発。

大胸筋皮弁による再建が行われた。切除断端は陰性であっ たが， $\mathrm{pN}(+) 4$ 個で被膜外浸潤を伴っていたため術後照 射を追加した。6 月月後の CT 撮影で咀嚼筋隙再発を認め たため追加切除を行った。その後局所・頸部再発はみられ なかったが, 肺転移のため 11 か月後に原病死となった。

症例 2（図 2）は78歳男性，右側上顎歯肉扁平上皮癌 （T4aN2bM0）で，全頸部郭清変法，上顎骨亜全摘，大胸 筋皮弁による再建が行われた。切除断端は陰性であった が $\mathrm{pN}(+) 3$ 個で被膜外浸潤を認め, 術後治療の適応と考 えられたが，年齢その他の理由でそのまま経過観察を行っ た。10 か月後の CT 撮影で咀嚼筋隙再発を認め, 追加切 除を行った。 2 年 7 か月（再手術から 1 年 9 か月）後現在, 経過良好である。

\section{2. 頸部再発例}

頸部郭清を行った 199 例中, 郭清を行った側に頸部再発 を生じた症例（局所再発に伴う頸部再発例や反対側の後発 転移例を除く）が 12 例（6.0\%）にみられた。この 12 例 のうち最終的に頸部が制御できたのは 3 例のみで，そのう ち 2 例はその後遠隔転移を生じた。このように頸部郭清後 に同側頸部再発を生じた場合, 予後は著しく不良であっ た。以下に頸部再発を生じた代表例を供覧する。

症例 3 (図 3) は 43 歳男性, 右側舌扁平上皮癌 (T2N1M0) で, 右側全頸部郭清変法, 舌半側切除, 前腕皮弁による再 建が行われた。切除断端は陰性で $\mathrm{pN}(+) 1$ 個, 被膜外浸 潤はなかった。 5 か月後に患側舌骨傍領域に再発を認め再
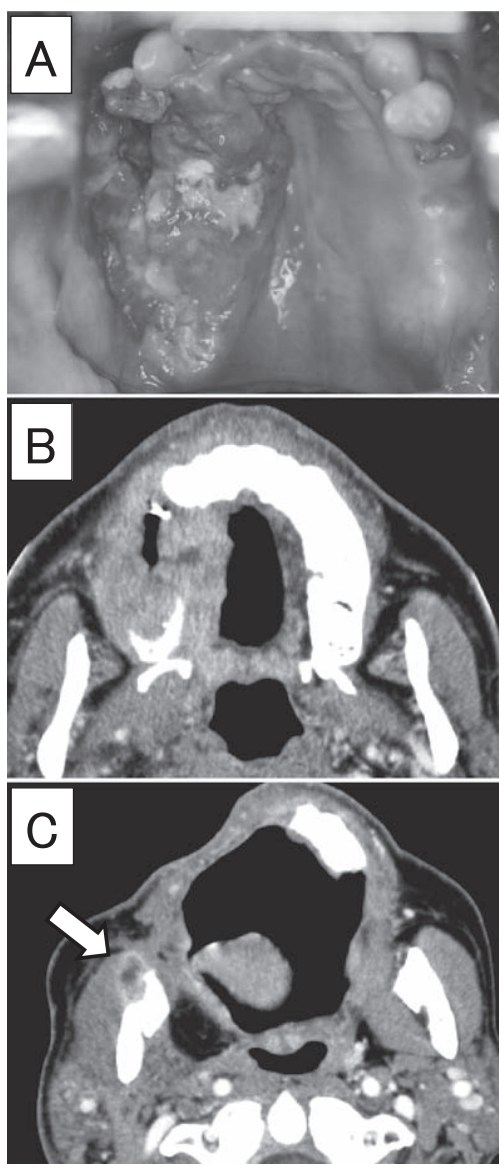

図 2 症例 $2 \mathrm{~A}$ ：初診時口腔内。B：翼突筋へわずか に浸潤していた。C：10 か月後咀嚼筋隙より再発。 


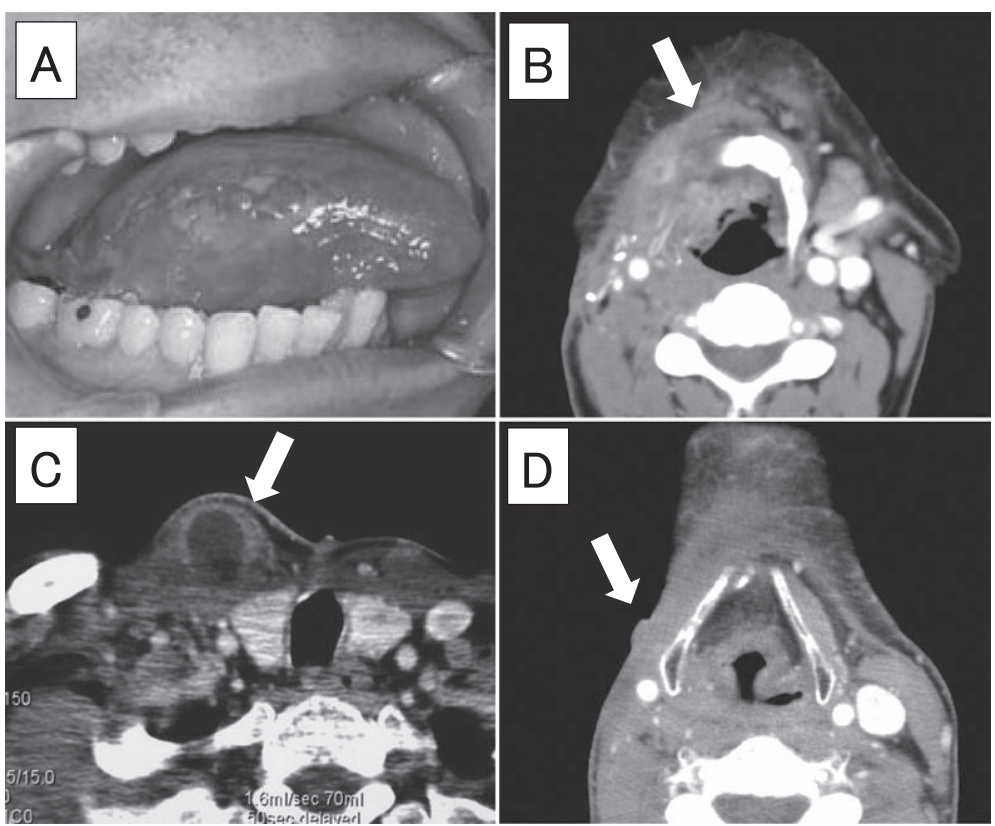

図 3 症例 3 A : 初診時口腔内, B : 5 か月後舌骨傍領域に再発。C：さらに 6 か月後鎖骨上窩に再発。D：さらに 2 か月後に舌骨傍領域に再発。

手術を行った。再手術から 6 か月後に患側鎖骨上窩に再発 を認め再度手術を行った。しかし 3 回目の手術から 2 か月 後に舌骨傍領域再発の部位の近傍の皮下から再発を生じ, 初診 1 年 11 か月後に原病死となった。

症例 4（図 4) は70 歳男性, 左側下顎歯肉扁平上皮癌 (T4aN2cM0), 右側上顎歯肉扁平上皮癌（T2），右側煩粘 膜扁平上皮癌（T2）の口腔内同時性 3 重癌で, 両側全頸 部郭清変法, 下顎骨区域切除, 上顎骨部分切除, 頓粘膜切 除, 遊離腸骨皮弁による再建が行われた。切除断端は陰 性, $\mathrm{pN}(+) 2$ 個（両側 1 個ずつ）被膜外浸潤はなかった。 6 か月後に左側の level $2 \mathrm{~b}$ に再発を認め再手術を行った。 再手術から 3 か月後にさらに後方から再発を認め, 再度手術 を行い, 初診から 2 年 4 か月後現在腫瘍なく生存中である。

\section{3. 手術以外の治療法が奏功した局所・頸部再発例}

上に述べたように局所・頸部再発例の救済手術の成功率 は決して高くない。また救済手術そのものが適用できずに それ以外の治療法を選択せざるを得ない場合も少なくない が, 手術が不可能な場合はさらに救済の可能性は低くな る。しかし中には手術以外の治療法で制御できる場合もあ り，そのような症例を呈示する。

症例 5（図 5) は 73 歳男性, 左側下顎歯肉扁平上皮癌 （T4bN0M0）で, 全頸部郭清変法, 下顎骨半側切除, 腹直 筋皮弁による再建が行われた。切除断端陰性, $\mathrm{pN}(-)$ で あった。5 か月後に咀嚼筋隙に再発を認め, 再手術を説明 したが患者の同意が得られず，放射線治療（IMRT）60Gy を施行, CR が得られ初診から 7 年 1 か月後現在腫瘍なく 生存中である。
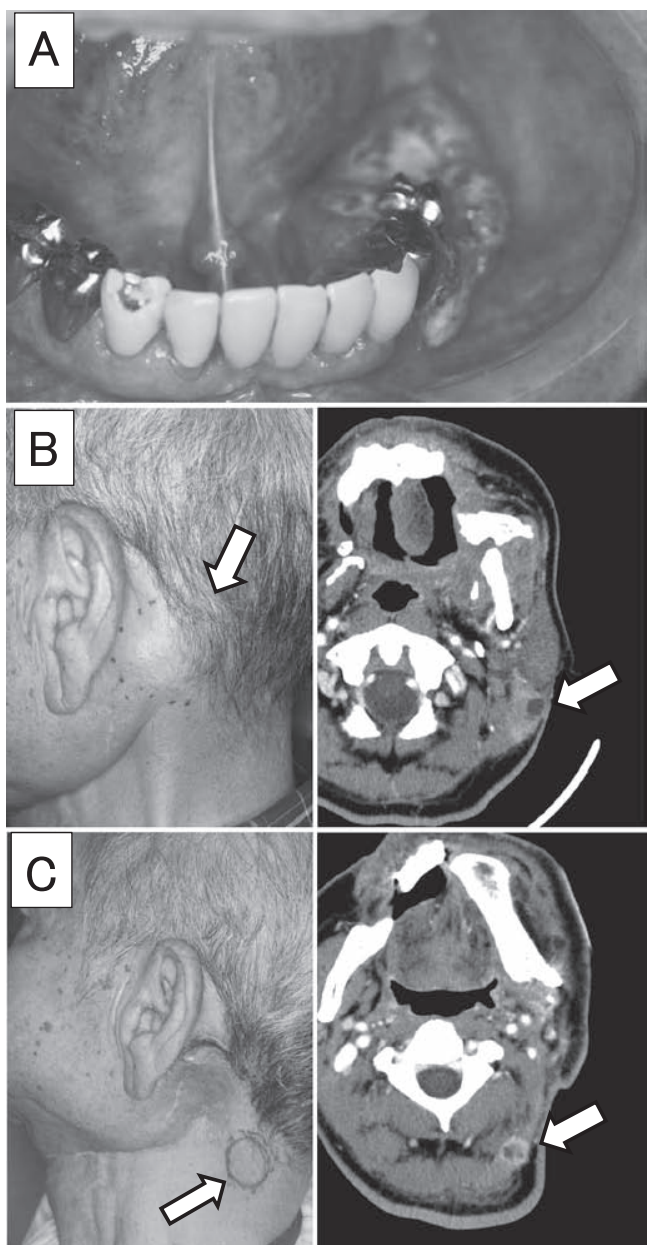

図 4 症例 4 A : 初診時口腔内。 B : 6 か月後 level $2 \mathrm{~b}$ に再発。C :さらに 3 か月後後方より再発。 


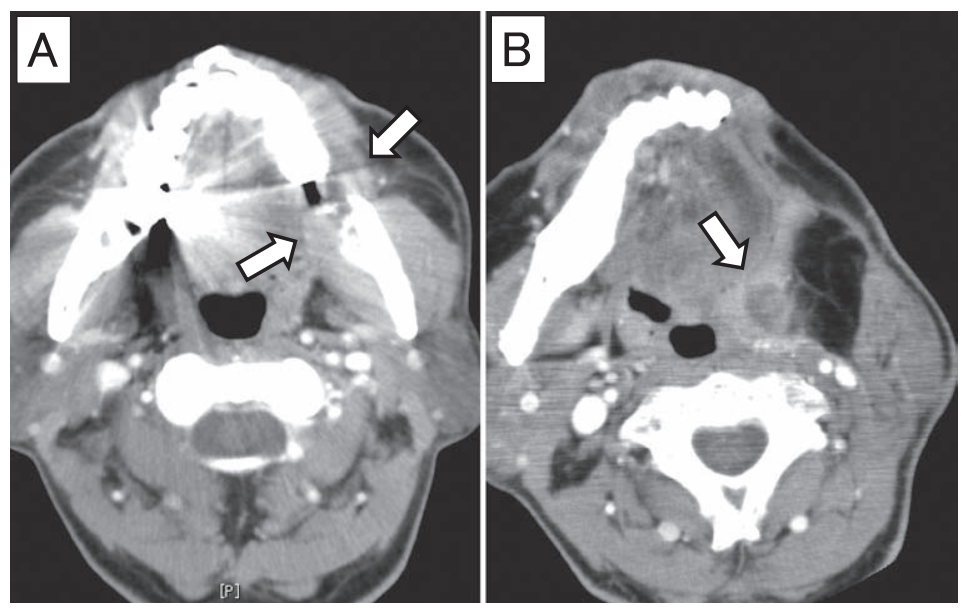

図 5 症例 5 A : 初診時 $\mathrm{CT}$ 。内側翼突筋に浸潤。B $: 5$ か月後咀嚼筋隙に再発。
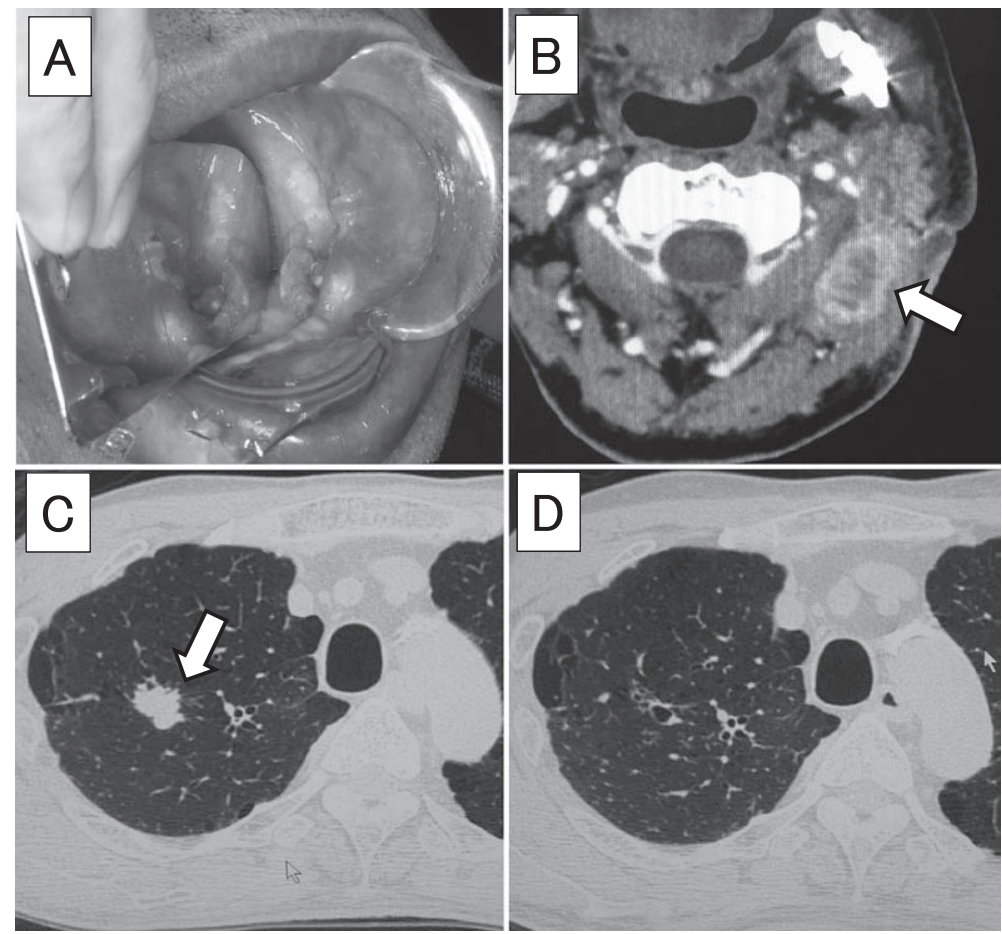

図 6 症例 6 A : 初診時口腔内。顎舌骨筋に浸潤していた。B：2か月後 level $2 \mathrm{~b}$ に再発。C：同時期に肺転移を生じた。 D : セツキシマブーパクリタ キセルにて肺転移は消失。

症例 6（図 6）は 60 歳男性, 左側下顎歯肉扁平上皮癌 （T4aN0M0）で，全頸部郭清変法，下顎骨区域切除，腓骨 皮弁による再建を施行した。切除断端㓌性, $\mathrm{pN}(-)$ で あった。2 か月後に level $2 \mathrm{~b}$ および肺への転移を認めたた め, 放射線治療 $60 \mathrm{~Gy}+\mathrm{CDDP}\left(100 \mathrm{mg} / \mathrm{m}^{2} \times 3\right.$ 週ごとに 3 クール）を行った。頸部転移, 肺転移とも NCの判定で あったため引き続いてセツキシマブ+パクリタキセルの 化学療法を 7 クール施行, その後はセツキシマブ単独投与 にして治療を継続中である。セツキシマブ+パクリタキ
セル 5クール目に頸部転移, 肺転移とも画像上 CR となり, $\mathrm{CR}$ と判定してから 5 か月（現在セツキシマブ 24 クール 施行中）後現在, CR 状態が維持できている。

症例 7（図 7) は 78 歳女性, 右側下顎歯肉扁平上皮癌再 発 $(r T 2 \mathrm{~N} 2 \mathrm{bM} 0)$ で, 3 年前に他医で左下䫈歯肉癌により 下顎骨区域切除が施行されている。右側全頸部郭清変法, 下顎骨辺縁切除が行われ, 切除断端陰性, $\mathrm{pN}(+) 2$ 個, 被膜外浸潤はなかった。3 か月後対側 level 1 , level $5 \mathrm{~b}$ お よび上縦隔リンパ節への転移を認め, 放射線治療 $60 \mathrm{~Gy}+$ 


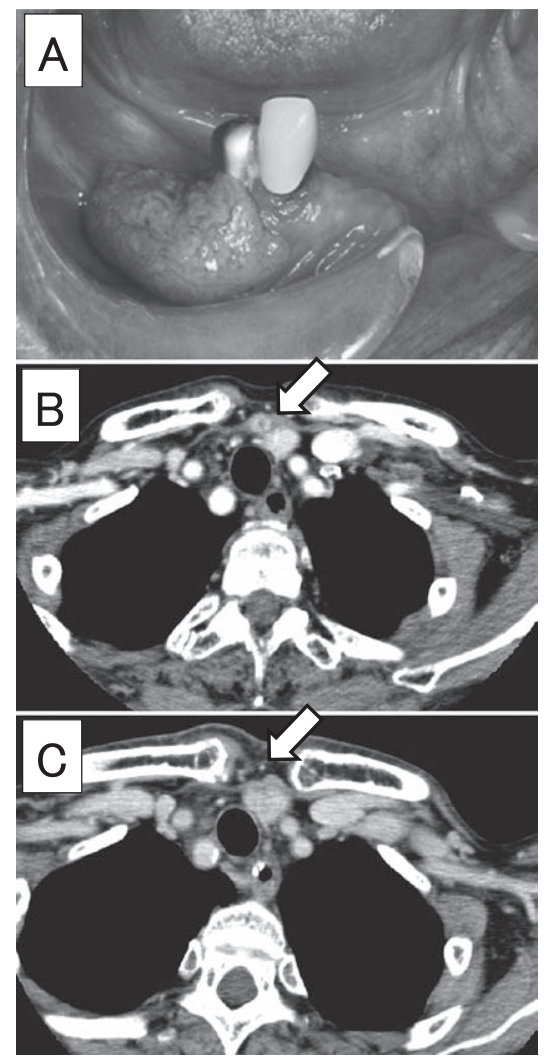

図 7 症例 $7 \quad \mathrm{~A}$ ：初診時口腔内。 $\mathrm{B}: 3$ か月後上縦隔リ ンパ節を含んだ多発性リンパ節転移を認めた。C : 照射＋セツキシマブによりリンパ節転移は消失。
セツキシマブ投与を行ったところ CR が得られた。 1 年後 に他病死するまで腫瘍の再発は認められなかった。

症例 8 (図 8) は 51 歳男性, 右側舌扁平上皮癌 (T3N2bM0) で, 右側全頸部郭清変法, 舌半側切除, 前外側大腿皮弁に よる再建を行った。切除断端陰性, $\mathrm{pN}(+) 4$ 個で被膜外 浸潤を認めたため, 放射線治療 66Gy + CDDP (100mg/ $\mathrm{m}^{2} \times 3$ 週ごとに 3 クール) を施行した。 4 か月後に対側頸 部に再発したため左側全頸部郭清変法を行った。再手術か ら 5 か月後に患側舌骨傍領域に再発を認め, 京都大学原子 炉実験所においてホウ素中性子捕捉療法（BNCT）を行い CR が得られた。初診から 1 年後に肺転移を生じ, セッキ シマブ+パクリタキセルを 6 クール行い CR が得られ, そ の後はセツキシマブ単独投与を 40 クール行った。その後 肺転移の再発を認め, 再度肺転移に対して京都大学原子炉 実験所において BNCT を施行, 現在セツキシマブ単独投 与中である。完全には腫瘍は消失していないが, 舌骨傍領 域に再発し手術不能と判断してから, 2 年 2 か月後現在も 通常の社会生活を送っている。

\section{考察}

筆者が以前所属していた施設では口腔癌の手術後局所再 発は 1980 年代には $21.4 \%$ であったが 2000 年代には $7.1 \%$ と著明に減少した ${ }^{1,2)}$ 。これは画像診断の進歩と, 遊離皮

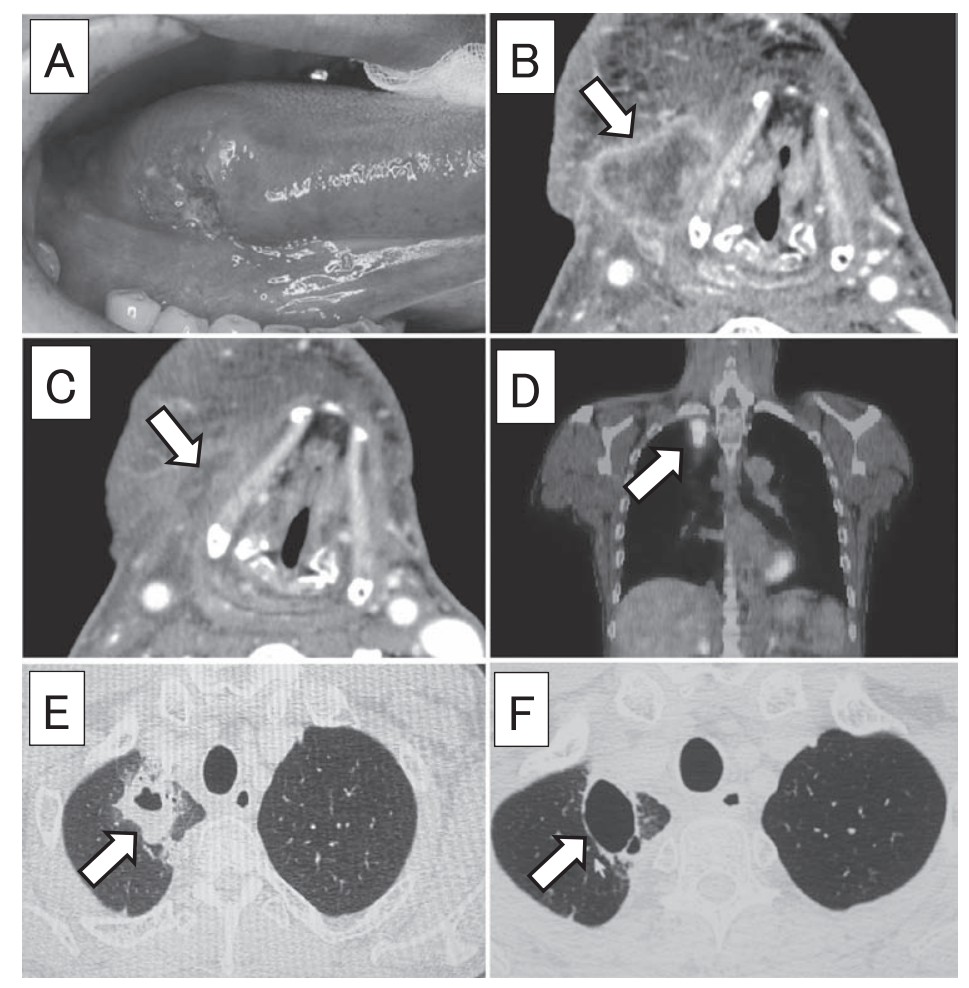

図 8 症例 $8 \mathrm{~A}$ ：初診時口腔内。B： 5 か月後舌骨傍領域に再発。C : BNCT 終了 3 か月後。再発腫瘍は 消失した。 $\mathrm{D} \cdot \mathrm{E}: 1$ 年後肺転移出現。 $\mathrm{F}:$ セツキシマブ+パクリタキセル 6 クールで肺転移巣消失。 
弁術などの再建外科の進歩の恩恵であると考えられる。ま た，ヨード染色法の確立により早期舌癌の局所再発がほ ほ皆無になったことも全体の再発率を低下させた要因で ある3)。しかし依然として局所再発を生じる場合があり， いったん再発をきたすと, 今回検討したように救済手術を 行っても治療成績は満足できるものではない。また, 頸部 再発については再発後の救済治療はさらに困難となる。そ のため過去の再発例の特徵を把握し再発を予防するための 対策を講じることは重要である。

著者はこれまで口腔癌の局所再発，特に手術法からみた 再発の要因について報告してきた。下顎歯肉癌については 局所再発は進展例よりもむしろ早期例で辺縁切除をした症 例にみられること, 軟組織再発が多く骨周囲の軟組織切除 が重要であること, 口底癌についても比較的早期例で下顎 骨辺縁切除例に再発例がしばしばみられることなどについ て指摘した ${ }^{1,4-6)}$ 。舌癌については小線源治療と比較した手 術法の優越性 ${ }^{7}$, 周囲粘膜の異型上皮の有無と再発との関

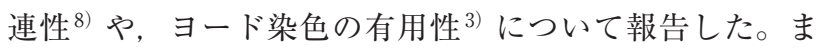
た, 術前化学療法を行うと, 縮小手術は行わないという 戦略であっても結果として局所再発は増加すること ${ }^{9-12)}$, これには治療抵抗性の癌幹細胞様細胞の選択的残存が関与 している可能性があること吕) などを報告してきた。これ らの臨床研究の結果をもとに対策を講じることにより局所 再発率は確実に低下してきたが，今回の検討でも手術を施 行した症例の約 $8 \%$ に局所再発を生じているのが現状であ る。以前報告した局所再発率 ${ }^{2)}$ と比べて最近の症例におい ても再発率が減少していないのは, 手術適応の拡大, すな わち以前なら手術の適応外としていた症例に対しても積極 的に手術を施行するようになったことがその理由と考えられ る。現在, 進展癌に対して手術を行う上で局所再発と関連 する最も大きな要因は，咀嚼筋隙再発であると考えている。

術前より咀嚼筋隙に進展している場合には T4b と分類 され，基本的には手術不可能と考えられてきた。日本口腔 がん臨床研究グループ (JOOG) では参加施設より T4b 症 例を収集しその治療成績について検討した結果，T4bで あっても必ずしも手術不能ではなく，手術を施行した 99 例の 5 年疾患特異的生存率は $54.3 \%$ であることを 2013 年 に報告した（栗田 浩ら, 第 58 回日本口腔外科学会総会, 論文作成中)。しかし今回呈示した症例 $1 ， 2$ のように咀嚼 筋隙再発は著者の経験では局所再発例の大半を占めている のも事実である。このことから, 同部に進展した口腔癌の 切除を行う場合には, 従来の切除安全域という概念ではな く,「咀嚼筋隙郭清」という概念に基づいた手術を行うこ とが必要であると考えている。

咀嚼筋隙は咬筋筋膜と翼突筋膜に囲まれる隙で, 咬筋, 側頭筋，内外側翼突筋，三叉神経第 3 枝，下顎骨などが含 まれる ${ }^{14)}$ 。外側上方では頓骨弓部から深側頭筋膜浅葉に,

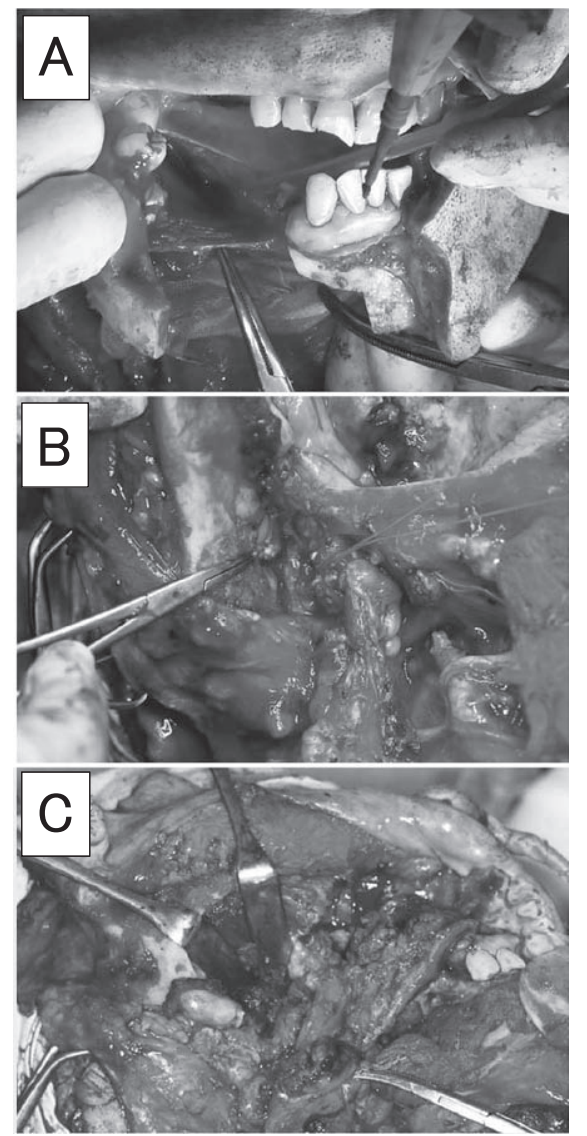

図 9 内側咀嚼筋隙郭清。A : mandibular swing により術野を展開。B：顎舌骨筋, 内側翼 突筋，下歯槽神経血管束を下顎骨内面より 切離。C：内外側翼突筋を含めて下顎骨の 内側組織を頭蓋底まで郭清。

筋突起から深側頭筋膜深葉に移行し，両葉間に側頭隙を形 成する。内側の境界は頓咽頭筋膜で, 深部は内側翼突筋膜 が翼状突起外側板内側面から棘孔内側の中頭蓋底骨に付着 する。手術を行う立場からは，咀嚼筋隙は下顎骨を境に内 側（翼突下顎隙，内外側翼突筋，翼口蓋窩に相当）および 外側（咬筋，側頭筋，側頭隙）に分けて考えることができ る。腫瘍の進展により下顎骨半側切除も含めて咀嚼筋隙の 内容物をすべて切除する「全咀嚼筋隙郭清」と, 内側咀嚼 筋隙のみを郭清する「内側咀嚼筋隙郭清」の二つの術式が 考えられるが, 全咀嚼筋隙郭清を行うと顔貌の変形も含め てかなりの侵襲となることや, 実際には咀嚼筋隙の内側へ の進展が問題となるケースが大多数であることから, 内側 咀嚼筋隙郭清の適応となることが多い。内側咀嚼笳隙郭清 は頸部郭清に引き続いて下唇および下顎骨を離断し, 顎舌 骨筋と内側翼突筋を下顎骨内面から剥離，続いて下歯槽 神経血管束も下顎骨で結惄切断し下顎骨を後上方に翻転, 関節頭から外側翼突筋を切離し, 外内側翼突筋を含めて 翼状突起あるいは頭蓋底まで郭清するものである（図 9)。 


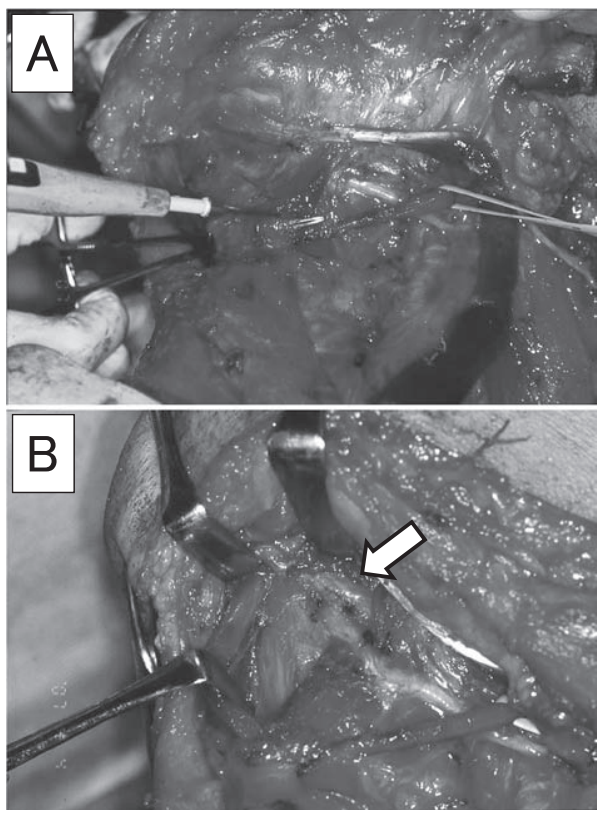

図 10 舌リンパ節へのアプローチ。A：顎舌 骨筋を舌骨直上で切離, または前方に 牽引。 B : 舌下神経が舌筋内に入る部 位付近に外側舌リンパ節が存在する。

必要に応じて関節頭をいったん脱臼させると十分な視野を 得ることができる。郭清部には筋皮弁による再建が必須 で, 咽頭腔を狭く再建し, 術後の燕下障害の軽減をはかる 工夫が重要である。

頸部再発については郭清範囲側の再発例の予後は著しく 不良であった。最近頸部郭清に招いてレベル 5 やレベル $2 \mathrm{~b}$ を省略するという考えもあるが, 今回報告したように レベル $2 \mathrm{~b}$ の再発も認めたことから, 著者は $\mathrm{N}(+)$ 例に おいてはエビデンスのない安易な郭清範囲の縮小は避ける べきであると考えている。副神経だけではなく頚神経の運 動根を可及的に温存することにより, 全頸部郭清であって も機能障害を最小限にすることができる ${ }^{15)}$ 。また, 舌骨傍 領域の再発もしばしばみられた。同部の再発はレベル $1 \sim 2$ の転移リンパ節の被膜外浸潤が原因になることもあ るが, 外側舌リンパ節転移が重要な原因を占めていると考 えられる。著者らは以前に舌リンパ節転移症例を紹介し 同リンパ節への外科的アプローチ法について報告した ${ }^{16)}$ 。 その要点は, 頸部郭清時に顎舌骨筋を舌骨付着部直上で切 離または前方に牽引し舌下神経が前方から上方に走行を転 じ舌筋内に侵入する部位で外側舌リンパ節の存在を確認す るというものである（図 10）。しかし舌リンパ節を郭清範 囲にすべて含めることには機能障害の面からも問題が多 く, 同リンパ節の取り扱いについては今後の検討が必要で ある。

著者は NCCN ガイドラインに準じて術後再発高リス

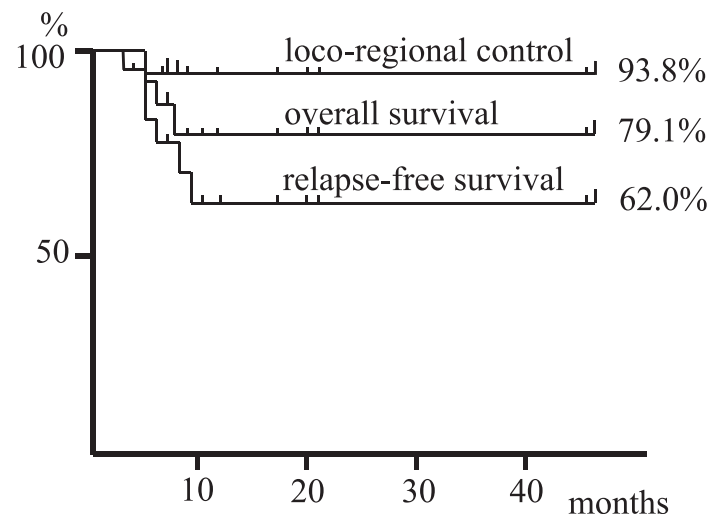

図 11 高用量 CDDP を用いた術後化学放射線治療を施 行した再発高リスク例の局所・頸部制御率, 無 再発生存率, 全生存率。局所・頸部の制御は良 好であるが遠隔転移死あるいは遠隔転移担癌生 存中患者が多い。

ク例に対して標準治療としての化学放射線同時併用療

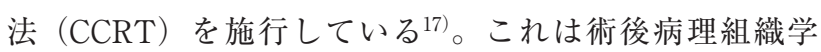
的に断端陽性, 被膜外浸潤を認めた場合, シスプラチ ン $100 \mathrm{mg} / \mathrm{m}^{2}$ を 3 週毎に 3 クール投与し, 同時に放射線 $66 \mathrm{~Gy}$ を照射するものである ${ }^{18,19)}$ 。著者は前任の神戸大学 で 2008 年より, 現在の長崎大学で 2011 年より本療法を 施行してきたが，再発高リスク例であるにもかかわらず, 局所・頸部再発は非常に少ないことを確認している（図 11)。本療法はシスプラチン $100 \mathrm{mg} / \mathrm{m}^{2} \times 3$ クールおよび $66 \mathrm{~Gy}$ の照射と, これまで本邦で広く行われてきた補助療 法の regimen からするとはるかに高用量の薬剤を投与す るものであるが，日本人に対しても実施可能であることが 報告されている ${ }^{20,21)}$ 。腫瘍内科医など医科との連携は必須 であるが, 再発高リスク例に対して唯一有效性が証明され ている治療であり, 積極的に取り入れることが本邦の口腔 外科医にも求められる。問題点としては対象症例の選別, すなわち被膜外浸潤の診断基準が定まっていないことが挙 げられる。単施設の研究ではあるが, 被膜外浸潤には顕微 鏡的な浸潤は含めずに周囲脂肪組織に広く進展したものの みを含めて本療法を適応とするべきであることを報告し た ${ }^{22)}$ 。また，本療法を施行すると局所・頸部制御率は向 上する可能性があるが，遠隔転移を抑制することができる か, Overall survival（OS）を改善することができるかど うかについては意見の一致をみていないのが現状である。

一方今回報告したように，セツキシマブにより遠隔転移 巣の消失を認めた症例も数例経験したが, これは従来の殺 細胞性の抗癌剤ではほとんどみられなかった特徵である。 今後標準治療としての CCRT に分子標的薬を組み合わせ ることにより, 局所・頸部再発だけではなく遠隔再発を制 御することも十分に可能になることが期待できる。 


\section{結語}

口腔扁平上皮癌の局所・頸部再発例の現状について後ろ 向きに検討した。また, 再発腫瘍に対する手術以外の治療 法として BNCT やセツキシマブを含んだ治療法が著効を 示した症例を呈示した。さらに, 再発を予防するための対 策として, 咀嚼筋隙内側郭清法, 舌リンパ節へのアプロー チ法, 国際標準治療としての術後化学放射線療法について 考察を行った。

本論文について申告すべき利益相反状態はありません。

\section{文献}

1）梅田正博, 大森昭輝, 他：口胩粘膜扁平上皮癌の手術後原発 单再発に関する臨床的検討. 口腔腫瘍 7:91-100, 1995.

2）梅田正博, 南川 勉, 他：口胅扁平上皮癌の治療法と予後に 関する臨床的検討 1) 手術例の原発巣制御について. 口腔 腫瘍 $18: 65-73,2006$.

3) Umeda, M., Shigeta, T., et al.: Clinical evaluation of Lugol's iodine staining in the treatment of stage I-II squamous cell carcinoma of the tongue. Int J Oral Maxillofac Surg 40 : 593-596, 2011.

4）武 宜昭, 梅田正博, 他：下顎歯肉扁平上皮癌の臨床的・病 理組織学的検討. 日口外誌 $43: 263-269,1994$.

5）武宜昭, 梅田正博, 他：下顎歯肉扁平上皮癌における下 顎骨切除方法と原発巣再発との関係について. 口科誌 45 : 51-56, 1996.

6）奥 尚久, 梅田正博, 他：口底扁平上皮癌における下顎骨切 除方法と原発巣再発との関係について. 口科誌 $45: 236-$ 268, 1996.

7) Umeda, M., Komatsubara, H., et al.: A comparison of brachytherapy and surgery for the treatment of stage I-II squamous cell carcinoma of the tongue. Int J Oral Maxillofac Surg $34: 739-744,2005$.

8) Umeda, M., Nishimatsu, N., et al.: Late local recurrence of squamous cell carcinoma of the oral cavity. Asian J Oral Maxillofac Surg 11 : 131-136, 1999.

9) Umeda, M., Komatsubara, H., et al.: Lack of survival advantage in patients with advanced, resectable squamous cell carcinoma of the oral cavity receiving induction chemotherapy with cisplatin (CDDP), docetaxel (TXT) and 5-fruorouracil (5FU). Kobe J Med Sci 50 : 189-196, 2004.
10）柳本惣市，山田慎一, 他：舌癌における術前化学療法が切除 断端に及ぼす影響について。頭頸部癌 39：435-442, 2013.

11) Yanamoto, S., Yamada, S., et al.: Clinicopathological risk factors for local recurrence in oral squamous cell carcinoma. Int J Oral Maxillofac Surg $41:$ 1195-1200, 2012.

12) Yanamoto, S., Yamada, S., et al.: Predictors of locoregional recurrence in T1-2N0 tongue cancer patients. Pathol Oncol Res $19:$ 795-803, 2013.

13) Yanamoto, S., Yamada, S., et al.: Expression of the cancer stem cell markers CD44v6 and ABCG2 in tongue cancer: Effect of neoadjuvant chemotherapy on local recurrence. Int J Oncol $44: 1153-1162,2014$.

14）梅田正博, 古森孝英 : 臨床のための隙の解剖. 日本口䏶外科 学会 (編) : 口腔外科ハンドマニュアル'10, クインテッセン 又出版, 東京, 2010, 137-143.

15) Umeda, M., Shigeta, T., et al.: Shoulder mobility after spinal accessory nerve sparing modified radical neck dissection in oral cancer patients. Oral Surg Oral Med Oral Pathol Oral Radiol Endod 109 : 820-824, 2010.

16) Umeda, M., Minamikawa, T., et al.: Metastasis to the lingual lymph node in patients with squamous cell carcinoma of the floor of the mouth: Report of two cases. Kobe J Med Sci $55: 67-72,2009$.

17) Yamada, S., Yanamoto, S., et al.: Feasibility of postoperative concurrent chemoradiotherapy in Japanese patients with oral squamous cell carcinoma showing high-risk factors for recurrence. J Oral Maxillofac Surg Med Pathol, 2014 (in press).

18) Cooper, J.S., Pajak, T.F., et al.: Postoperative concurrent radiotherapy and chemotherapy for high-risk squamous-cell carcinoma of the head and neck. N Engl J Med 350 : 19371944, 2004.

19) Bernier, J., Domenge, C., et al.: Postoperative irradiation with or without concomitant chemotherapy for locally advanced head and neck cancer. N Engl J Med 350 : 19451952, 2004.

20) Kiyota, N., Tahara, M., et al.: Phase II feasibility trial of adjuvant chemoradiotherapy with 3-weekly cisplatin for Japanese patients with post-operative high-risk squamous cell carcinoma of the head and neck. Jpn J Clin Oncol 42 : 927933, 2012.

21）大鶴光信, 太田嘉英, 他：口腔扁平上皮癌術後ハイリスク群 に㧍ける 3 週毎シスプラチンを用いた化学放射線療法の検討. 口腔腫瘍 $25: 1-6,2013$.

22）山田慎一, 柳本惣市, 他：口腔扁平上皮癌の頸部リンパ節転 移における被膜外浸潤の進展度分類の検討．頭頸部癌， 2014 (印刷中). 


\title{
Present status and prospects of loco-regional recurrence in patients with oral cancer
}

\author{
Masahiro Umeda ${ }^{1)}$, Soichi Yanamoto ${ }^{1)}$, Shin-ichi Yamada ${ }^{1)}$, \\ Tsutomu Minamikawa ${ }^{2)}$, Yasuyuki Shibuya ${ }^{2)}$ and Takahide Komori ${ }^{2)}$ \\ 1) Department of Clinical Oral Oncology, Nagasaki University Graduate School of Biomedical Sciences \\ (Chief: Prof. Masahiro Umeda) \\ 2) Department of Oral and Maxillofacial Surgery, Kobe University Graduate School of Medicine \\ (Chief: Takahide Komori)
}

\begin{abstract}
A retrospective study was conducted of loco-regional recurrence in 324 patients with squamous cell carcinoma of the oral cavity treated with surgery. Local recurrence occurred in $26(8.0 \%)$ patients: $4.3 \%$ for T1-2 patients, and $17 \%$ for T3-4. Among them, only 12 patients were salvaged, and especially those with advanced stage showed extremely poor prognosis. The most frequent recurrent site was the masticatory space.

Neck recurrence was seen in 12 of 199 patients (6.0\%) who underwent neck dissection. Three patients had their necks cured, although two of them developed distant metastasis. The prognosis of those with neck recurrence was extremely poor. The most frequent recurrent site was the parahyoid bone region.

Prophylaxis for loco-regional recurrence was discussed including internal masticatory space dissection, surgical approach to the lingual lymph nodes, and postoperative chemoradiotherapy with high dose cisplatin.
\end{abstract}

Key words : oral cancer, local recurrence, neck recurrence, prognosis

Requests for reprints to: Dr. Umeda M., Department of Clinical Oral Oncology, Nagasaki University Graduate School of Biomedical Sciences, 1-7-1, Sakamoto, Nagasaki, 852-8588, Japan 